УДК 302.12.

https://doi.org/10.52058/2708-7530-2021-4(10)-73-87

Лерник Світлана Степанівна докторант Міжрегіональної Академії управління персоналом, вул.Фрометівська, 2, м. Київ, 03039, тел.: (050) 389-97-79, e-mail: aspirant@iapm.edu.ua, https://orcid.org/0000-0001-7413-9425

\title{
СВІТОВА ГЛОБАЛІЗАЦІЯ: ПОЛІТИКО-ЕКОНОМІЧНИЙ, ДУХОВНО- КУЛЬТУРНИЙ ВИМІРИ ТА ПРОГНОЗ ПОДАЛЬШОГО РОЗВИТКУ
}

Анотація. Розглядаються найсуттєвіші аспекти сучасного політикоекономічного та духовно-культурного розвитку світової глобалізації, притаманних їй процесів та дається науково-соціальний прогноз іiї подальшого поглиблення. Концентрується увага на складних і неоднозначних проблемах і протиріччях, породжених глобалізацією, на тих iї аспектах, що ще не набули належного наукового розгляду у суспільних науках. Робиться акцент на реальній потребі цілісного, комплексного, синергетичного аналізу недостатньо досліджених проблем світової глобалізації.

Відмічено, що найхарактернішими формами глобалізації $є$ політична, економічна та культурна, а тому існує реальна потреба детальнішого аналізу і пояснення цих відносин як у політичному аспекті, так і суто національному плані, відносно окремо взятих держав.

Визначено, глобалізацію часто асоціюють із гемогенізацією (коли усі частини й елементи будь-чого є подібними, ідентичними). Але, як протиріччя, спостерігається і потужний розвиток різноманіття у всіх сферах людського життя. Одностайним є також висновок про те, що глобалізація не лише радикально змінила світ але й надалі буде породжувати й стимулювати такі зміни. При цьому гостро постає питання щодо «глобалізації з людським обличчям», тобто, у який спосіб максимально використати глобалізаційні процеси в інтересах і на догоду людині, тобто з позитивним ефектом. Комплекс перерахованих та інших проблем теоретико-методологічного та практичного аспектів потребує перш за все розглянути глобалізацію у політичному, політологічному плані.

Зазначено, що в умовах глобалізації формування нових економічних відносин, наголосимо, відбувається в процесі функціонування і потужного розвитку міжнародної торгівлі, діяльності транснаціональних корпорацій, нової системи існування міжнародних фінансів. Як би то не було, а ці процеси помітно впливають і на соціально-економічний розвиток не лише високорозвинутих але i інших держав, і з цим не можна не рахуватися. 
Найскладніше, найсуперечливіше світова глобалізація позначилася саме на питаннях духовно-культурного життя суспільств, оскільки вона викликала потужні процеси формування єдиних соціальних просторів у ряді великих регіонів світу.

Ключові слова: глобалізм; світова глобалізація; політичні, економічні, духовно-культурні аспекти глобалізації; прогноз розвитку глобалізації на світовому і національному рівнях.

Lernik Svitlana Stepanivna doctoral student of the Interregional Academy of Personnel Management, Frometovskaya St., 2, Kiev, 03039, tel.: (050) 389-97-79, e-mail: aspirant@iapm.edu.ua, https://orcid.org/0000-0001-7413-9425

\title{
WORLD GLOBALIZATION: POLITICAL-ECONOMIC, SPIRITUAL- CULTURAL DIMENSION AND FORECAST OF FURTHER DEVELOPMENT
}

\begin{abstract}
The most significant aspects of the modern political, economic and spiritual and cultural development of world globalization, its inherent processes are considered, and a scientific and social forecast for its further deepening is given. Attention is focused on the complex and controversial problems and contradictions generated by globalization, on those aspects of it that have not yet received proper scientific consideration in the social sciences. Emphasis is placed on the real need for a holistic, complex, synergistic analysis of insufficiently studied problems of world globalization.
\end{abstract}

It is noted that the most characteristic forms of globalization are political, economic and cultural, and therefore there is a real need for more detailed analysis and explanation of these relations, both politically and purely nationally, in relation to individual states.

Certainly, globalization is often associated with hemogenization (when all parts and elements of anything are similar, identical). But, as a contradiction, there is a powerful development of diversity in all spheres of human life. It is also unanimous to conclude that globalization has not only radically changed the world but will continue to generate and stimulate such change. This raises the question of "globalization with a human face", ie, how to make the most of globalization processes in the interests and for the benefit of man, ie with a positive effect. The complex of the listed and other problems of theoretical-methodological and practical aspects needs to consider first of all globalization in the political, political plan.

It is noted that in the context of globalization, the formation of new economic relations, we emphasize, is in the process of functioning and powerful development of international trade, the activities of transnational corporations, a new system of 
international finance. Be that as it may, these processes significantly affect the socioeconomic development of not only highly developed but also other states, and this cannot be ignored.

The most difficult, most contradictory world globalization has affected the issues of spiritual and cultural life of societies, as it has caused powerful processes of formation of common social spaces in a number of large regions of the world.

Keywords: globalism; world globalization; political, economic, spiritual and cultural aspects of globalization, forecast of the development of globalization at the world and national levels.

Постановка проблеми. Сучасна глобалізація має загальносвітовий масштаб i характер, хоча i неоднозначно виявляє себе на розвитку окремих країн $\mathrm{i}$ суспільств. Вона стосується усіх сфер суспільного життя, характеризується як загальними, так і специфічними, суто національними особливостями свого прояву, що далеко неоднозначно трактуються у сучасних суспільних науках $\mathrm{i}$ потребують більш грунтовного наукового аналізу.

Сучасна глобалізація найсуттєвіше вплинула на трансформацію економічних, політичних і духовно-цивілізаційних відносин між країнами і суспільствами. Це незаперечний факт, підтверджений багатьма факторами і даними.

Найхарактернішими формами глобалізації $\epsilon$ політична, економічна та культурна, а тому існує реальна потреба детальнішого аналізу і пояснення цих відносин як у політичному аспекті, так і суто національному плані, відносно окремо взятих держав.

Якщо пам'ятати, що історія цивілізацій - це не лише війни, гострі катаклізми, протистояння імперій і держав, але й позитивний обмін, збагачення науковими, культурними і іншими здобутками людства, то сучасну глобалізацію маємо розглядати як у критичному, так і у позитивному плані. Це - вкрай необхідний дуалістичний науковий підхід до розгляду суті, розвитку та проявів світової глобалізації.

Врешті, виникає багато питань щодо прогнозу світової глобалізації визначення того, у який спосіб глобалізаційні процеси позначаються на житті людини, великих соціумів, на долі держав і суспільств загалом. Тут є багато різноманітного характеру прогнозів, які слід не просто враховувати але предметно аналізувати [1-17].

Аналіз останніх досліджень і публікацій. Проблеми світової глобалізації досліджують багато зарубіжних та вітчизняних вчених, серед яких виділяємо праці І.Алєксєєнка, Г.Аніліоніса, І.Бека, В.Беренса, О.Білоруса, С.Вовканича, І.Воронова, В.Журавльова, Н.Зотової, М.Косолапова, І.Кресіної, Д.Медоуза, О.Неклессі, Й.Рендерса, Д.Сороса, В.Співака, Дж.Стігліца, А.Уткіна, М.Чешкова, 
О.Чумакова, В.Шейко, М.Шепелева та інших. При цьому виділяємо праці тих вчених, в яких особливий наголос робиться на впливі світових глобалізаційних процесів на модернізацію суспільств, людських відносин: М.Баймуратов, Р.Балабан, В.Бебик, В.Безродна, О.Долженков, В.Вовк, Ю.Ганжуров, В.Горбатенко, Л.Токар, Р.Червонюк, Ю.Якименко.

Українські дослідники О. Білорус та Ю. Маценко в монографії «Глобальна перспектива і сталий розвиток» (К. 2005. 411 с.) детально розглядають основні протиріччя сучасної глобалізації та ऑï вплив на сталий розвиток держав. А.Кудряченко, Ф.Рудич, О.Храмов аналізують вплив глобалізації на геополітичні процеси (див. Геополітика. К. 2004. 295с.). О.Богомолов, С.Борщук, В.Динилишин та інші дослідники зосереджував увагу на економічному аспекті глобалізації, а такі відомі фахівці як З.Борисенко, Д.Гелд, Мак-Грю Е. та ін. звертають увагу на глибокі протирічливі процеси, що породжує глобалізація (див. Гелд Д., Мак-Грю Е. Глобалізація - антиглобалізація. К., 2004. 145 с.) та ін.

Існує багато різноманітних наукових шкіл, теоретичних концепцій дослідження i пояснення феномену «глобалізація», серед яких виділяють: концепцію «Межі зростання» (фахівці Римського клубу, які зосереджують увагу на глобалізаційних економічних процесах); концепцію «сталого розвитку» (концентрують увагу на проблемах глобалізаційних демографічних процесів); концепція «універсального еволюціоаналізму» (зосереджуються на аналізі проблем розвитку біосфери, екологічної проблематики); концепція «контрольованого глобального розвитку» (зосередженість на питаннях моделювання глобального соціального розвитку людства); концепція світсистемного аналізу (концентрація уваги на проблемах глобалізованого світового економічного розвитку).

Разом 3 тим існують підстави констатувати, що за наявності достатньо великої кількості спеціальних наукових робіт, присвячених світовій глобалізації, маємо досить невелику джерельну базу, в якій розглядаються політикоекономічні, духовно-культурні аспекти цієї проблематики. Серед зарубіжних та вітчизняних досліджень у цій сфері виділимо перш за все праці В.Бебика [1], О.Білоруса і Д.Лукяненка [4], В.Горбатенка [6], В.Клочка [11], В.Михайлова [5], В.Співака [15], В.Халамендик [16] та А.Чумакова [17], які і було взято за основу при підготовці статті.

Метою статті $\epsilon$ теоретико-методологічне обгрунтування основних наукових підходів до пояснення феномену «світова глобалізація» та окреслення i характеристика специфіки політико-економічних, духовно-культурних та інших аспектів розвитку i прояву глобалізації на міжнародному (світовому) та національному рівнях.

Глобалізація - це загальна для фактично усіх країн світу система проблем, 
що реально існують перед людством. Ще наприкінці 60-х років XX століття такими проблемами постали: загроза ядерної війни, гонка озброєнь, нерівномірність розвитку різних регіонів світу, різноманітного характеру енергетичні, економічні, продовольчі, демографічні кризи, а на початок XXI століття до них додалися тероризм, інформаційні війни, світові епідемії типу коронавірусу тощо.

В цілому виділяють чотири основних теоретико-методологічних підходи до пояснення терміну «глобалізація». Перший, пов'язаний із розширенням зв'язків між найвіддаленішими частинами світу та поширенням спільних ідей, норм, цінностей, технологій. Другий - це виникнення й існування спільних для усього людства проблем. Третій пояснює глобалізацію як неухильне зростання й поширення так званих вселюдських інтересів, поглиблення взаємозалежності, взаємозв’язків між країнами i народами. Четвертий пов'язаний 3 поділом глобалізації на політичну, економічну, культурну, технологічну і т. ін. Така недостатня визначеність єства «глобалізації» не заважає, однак, їй реально існувати, даватися взнаки у всіх сферах людського буття, викликати потребу все більш поглибленого аналізу різноманітних глобалізаційних процесів.

Виклад основного матеріалу. Системоутворюючу ознаку, роль і планетарне значення феномену «глобалізація» надає найперше його походження - від англійського globe - «земна куля». В такому значенні цей термін, вважають, вперше використав відомий німецький політолог К.Ясперс у своїй праці «Джерела історії і іiі мета» (1948 р.) [5]. За іншими даними термін «глобалізація» належить англійському досліднику Р.Роберстону (1983р.). С, таким чином, немало різного роду теоретичних підходів та пояснень феномену «глобалізація», але залишається головне і найважливіше, саме з глобалізацією, притаманними їй процесами фактично у всіх сферах суспільного життя фахівці та пересічні громадяни пов'язують як позитивні, так і негативні процеси світового масштабу, хоча грунтовного осмислення ii наслідків все ще бракує. Беззаперечною залишається лише думка про об'єктивний характер цього явища, закономірність його розвитку, багатовимірність прояву.

Глобалізацію часто асоціюють із гемогенізацією (коли усі частини й елементи будь-чого є подібними, ідентичними). Але, як протиріччя, спостерігається і потужний розвиток різноманіття у всіх сферах людського життя. Одностайним є також висновок про те, що глобалізація не лише радикально змінила світ але й надалі буде породжувати й стимулювати такі зміни. При цьому гостро постає питання щодо «глобалізації з людським обличчям», тобто, у який спосіб максимально використати глобалізаційні процеси в інтересах і на догоду людині, тобто з позитивним ефектом. Комплекс перерахованих та інших проблем теоретико-методологічного та практичного аспектів потребує перш за все 
розглянути глобалізацію у політичному, політологічному плані.

Український політолог В.Бебик вірно робить акцент на тому, що наприкінці XX - початку XXI століть початкові глобалізаційні процеси мали місце переважно в економіці, як інтеграційний економічний процес та «визрівання загальнолюдського, планетарного розуміння екологічних, технологічних i техногенних проблем» [1, с.78]. До сьогодні до них додалися глобального характеру інформатизаційні процеси, проблеми захисту життя людини (тероризм, масові епідеміологічні захворювання, міграційні та ін. процеси). Сюди можна добавити і глобалізацію міждержавних, міжнародних відносин, що не обходять стороною ні одну країну світу: особливо на периферії, бо без взаємин з іншими, не може функціонувати жодне суспільство. Наявність широких інтеграційних, глобального характеру процесів дає підстави В.Бебику (і небезпідставно) вести мову про такі феномени як «глобальне громадянське суспільство», «глобальна держава» тощо. Хоча більш-менш усталеної наукової думки стосовно таких феноменів у сучасних суспільних науках поки що бракує, можна брати до уваги думку про те, що «глобальне громадянське суспільство» можна розглядати як планетарну сукупність усіх громадян світу, їх вільних об’єднань та асоціацій, що складають систему суспільних інститутів i відносин, котрі перебувають за межами новоствореної глобальної держави та пї директивного регулювання i регламентації» [1, с.79]. Навіть за фактів розпаду окремих держав (СРСР, Югославія і т. ін.), збільшення кількості нових суверених держав, світову глобалізаційну інтеграцію неможливо заперечувати.

Глобалізаційні процеси суттєво торкнулися питань трансформації систем влади і політичних режимів в багатьох країнах. 3 одного боку ці процеси мають місце за конкретних, специфічних умов окремо взятих країн, а, з іншого, на основі певних, фактично загальносвітових закономірностей. Так, по відношенню до систем влади і політичних режимів, це децентралізація влади, все помітніша реалізація принципу субсидіарності (поділ влади i розподіл владних повноважень), демократизація влади, суспільного життя тощо.

Глобалізація характеризується не лише протирічливими процесами інтеграції i деінтеграції, формуванням глобальної політичної системи, але й таким малозбагненним i недостатньо поясненим явищем як глобальне громадянське суспільство, під яким розуміють об’єднання людей, достатньо однотипних соціальних спільнот поза межами політики. Такі об'єднання намагаються вирішити найбільш значущі, загальні проблеми життя людей. До таких проблем відносять сировинну, продовольчу, демографічну, екологічну, енергетичну, проблему війни, миру та роззброєння, проблеми бідності і відсталості у розвитку. Це проблеми пов'язані: a) із взаєминами людини і природи (довкілля); б) iз безпосередніми суспільними відносинами; в) із розвитком самої людини та іï 
пристосуванням до навколишнього середовища. Вирішити такі проблеми, або, бодай, зменшити їх негативний вплив на життя людей - це шлях не лише збереження життя великої кількості людей, але й людської цивілізації загалом. Це, зокрема, яскраво підтвердили події 3 епідемією коронавірусу у світ, починаючи з березня-квітня 2020 року.

У політичному відношенні глобальних трансформацій зазнають політичні інститути і процеси як на національному так і на загальносвітовому рівнях.

Процес глобалізації характеризується появою, утворенням своєрідних наддержавних структур, входячи в які, або з боку яких, відчуваючи вплив, конкретна держава вимушена узгоджувати свої національні інтереси, цінності, потреби із інтересами не стільки інших держав, скільки таких структур. Чи це об’єднання країн «великої сімки», чи МОТ, чи Рада Європи, чи Світовий Банк, інше утворення, але воно й саме по собі не може існувати за наявності плюралізму інтересів. Більше того, з розпадом СРСР, як супердержави, практично глобалізація все більше стає однополюсною, такою де одна супердержава - США - диктує волю і інтерес більш малим державам.

В політичних процесах все гостріше даються взнаки проблеми моральності політики [16], доцільності політичних рішень, взаємовідносин політики і права. Досить дискусійним залишається питання про єдність політичного світу.

Врешті, серйозної переоцінки набувають питання суверенітету держав, розвитку громадянського суспільства, того, що відомий політолог С.Хантінгтон образно назвав «глобальною кризою ідентичності» [5, с.445]. Так, досліджуючи світові глобалізаційні процеси П.Герст і Г.Томпсон обгрунтовують по відношенню національних держав, - особливо тих, що формуються або радикально трансформуються, - «нову суверенність» [3, с.239]. Цей феномен ще вкрай недостатньо проаналізовано.

Молодий азербайджанський дослідник - політолог Ашар Даміров обгрунтовує цікавий термін «політична глобалізація», під яким розуміє «поступове зміцнення взаємодії між націями, цивілізаціями і етнокультурами, що веде до набуття взаємозв'язків і утворенню структур глобальної керованості, які інтегрують раніше роз'єднані фрагменти світу і тим самим ньому (управлінні) брати співучасть» [9, с.205]. Складно, сформульовано, це i, можливо, не зовсім зрозуміло. Те, що в умовах глобалізації взаємодія держав і суспільств стає набагато помітнішою - сумніві не викликає, а от з «глобальною керованістю» не все ясно: фактично сьогодні у світі такої керованості майже не помітно. Більше того, різка поляризація не лише держав (США, Китай, Індія, Німеччина, Англія і т.ін.), протистояння навіть окремих геополітичних регіонів (Свропа, Азія, Америка і т. ін.) виглядає більш помітною ніж політична інтеграція.

Домінуючим фактором світової глобалізації в XXI столітті все помітніше, як 
зазначалося, стає міжнародна економічна інтеграція як процес зближення, переплетення, адаптації національних господарств світового співтовариства. Нині перед кожною країною виникає крайня необхідність узгодження умов господарювання як на мікрорівні (в межах власної країни) так і на макрорівні (між країнами). Тобто, стан та особливості національної економіки будь-якої країни все більше стають залежними від: проференціальних зон (території з пільгами, особливостями в оподаткуванні, кредитуванні, таможенному регулюванні); функціонування так званих зон вільної торгівлі (ЗВТ); функціонування таможеного союзу; існування загального ринку і економічного союзу і т. ін.

Серед найгостріших проблем світової економічної інтеграції виділимо дві: міжнародний рух капіталу та світову міграцію робочої сили. Якщо перший процес помітно і найперше залежить від декількох десятків найбільш розвинутих країн світу, то другий, набуває все більш хаотичного, неврегульованого характеру. Страждають не лише слаборозвинуті країни, але й такі, що радикально трансформуються (сюди віднесемо й Україну), в яких ринкові відносини ще далеко не склалися.

В умовах глобалізації формування нових економічних відносин, наголосимо, відбувається в процесі функціонування і потужного розвитку міжнародної торгівлі, діяльності транснаціональних корпорацій, нової системи існування міжнародних фінансів. Як би то не було, а ці процеси помітно впливають і на соціально-економічний розвиток не лише високорозвинутих але і інших держав, $\mathrm{i}$ 3 цим не можна не рахуватися.

Найскладніше, найсуперечливіше світова глобалізація позначилася саме на питаннях духовно-культурного життя суспільств, оскільки вона викликала потужні процеси формування єдиних соціальних просторів у ряді великих регіонів світу. Найпомітнішим тут $є$ процес формування європейського соціального простору. Менше дослідженими i поясненими, при цьому, залишаються такі процеси в Азії, Африці, на інших континентах, які носять невиразний, специфічний, а то і локальний характер. У який спосіб поціновувати такі явища? Вочевидь, слушною є думка Г.Спенсера в тому плані, що «тільки ті зміни складають прогрес, які прямо чи опосередковано зумовлюють підвищення людського щастя» [12].

Зазначимо, однак, що соціокультурна трансформація сучасних соціумів в умовах глобалізації - далеко не позитивний і однозначний процес. В основі такої трансформації все гостріше постають проблеми національних мов, культурних цінностей, традицій, а, у зібраному, цілісному плані - національної, етнічної та інших соціальних ідентифікацій [11]. Все активніше стали предметом дискусії проблеми духовної реформації, універсалізації культури, глобальної антропокультурної кризи, надлюдського характеру цінностей і т. ін. 
В культурно-духовному відношенні глобалізація породила, поглибила i загострила одночасно специфічний дуалізм, по-новому обумовила проблему мультикультуралізму. В першому випадку, підпадаючи під вплив глобальної культури, люди намагаються, одночасно, утриматися у річищі самобутньої культури власного народу. Зробити це вдається далеко не усім. Таких країн як Канада, або Швейцарія, де певною мірою ця проблема вирішена, одиниці, у більшості країн маємо багато проблем - мовних, культурних, освітніх і т. ін.

Найсуттєвішим результатом широких геополітичних процесів є формування дедалі інтенсивнішого i активнішого глобального або, так званого, транснаціонального громадянського суспільства. Цьому сприяли не лише потужні процеси розвитку освіти, науки, нових технологій, що помітно збагачують не лише гуманітарну сферу. Виникли i продовжують виникати специфічні самоорганізовані проміжні групи людей, що $є$ відносно незалежними як від органів державної влади, так і від різного роду економічних агентів. Вони діють 3 метою утвердження власних інтересів i долаючи державні кордони. Цей суспільний феномен, однак, залишається мало дослідженим і поясненим як дієвий елемент активного громадського життя.

Якою є доля і у який спосіб вище означені проблеми світової глобалізації можуть бути вирішеними у подальшому - питання складне.

Є немало фахівців i точок зору, що досить скептично прогнозують глобалізаційний розвиток. Так, відомий німецький дослідник У.Бек стверджує, що майбутнє глобалізоване суспільство буде суспільством ризику. А такі дослідники як Е.Гіденс, І.Валлерстайн, А.Мартинеллі. П.Шталик та інші доводять, що в результаті глобалізації так звані горизонтальне розмаїття і вертикальна нерівність абсолютно не зникають, а, навпаки, зростають. «У світлі світових подій останніх років, - пишуть українські політологи В.Горбатенко і С.Бульбенюк, - не можна не погодитися з більшістю тверджень прихильників теорії «глобального суспільства ризику», а тому можна констатувати, що ризики та безпека стають рутиною повсякдення, а безпека стає нормою діяльності як окремих індивідів, так i держав» [6, с.145]. У зв'язку з цим та іншими аспектами, у світі має місце і досить помітний антиглобалістичний рух, основу якого становить протест проти формування так званих «суспільств масового споживання», а такі відомі фахівці як Е.Фромм, наприклад, взагалі скептично оцінює перспективи розвитку західних високорозвинутих суспільств.

Достатньо великою загрозою для суспільного розвитку на демократичних, гуманістичних засадах є те, що в умовах глобалізації з’являється загроза втрати національної ідентичності: людина все більше відчуває себе людиною світу, вибудовуючи свою діяльність на утилітаристських засадах, надаючи пріоритет суто власним інтересам, все менше ідентифікує себе зі своєю національною 
спільнотою. До цього додаються потужні міграційні процеси, "відплив інтелекту» з багатьох сфер суспільного життя. За таких умов проблема самоідентифікації гостро постає навіть перед великими державами (країнами) загалом, такими, наприклад, як Росія (Російська Федерація). Щоб зберегти хоча б основи такої ідентифікації російський політикум вдається навіть до таких крайнощів, як відродження авторитарної системи влади і основ функціонування цієї великої держави - колишньої імперії в моделі СРСР. Ще більш складними для аналізу є соціально-економічні та інші процеси, що розвиваються у таких супердержавах як США, Китай, де глобалізаційні процеси успішно використані з метою найперше зміцнення власної державності, суверенітету країн. Це приклади того, що процеси інтеграції і деінтеграції мають обопільний, навіть протирічливий характер.

Багато проблем сучасної глобалізації вирішуються в ході врегулювання міжнародних відносин між країнами та у пошуку інтегральних механізмів і форм подолання негативних процесів, що тут мають місце. Так, можна сповна погодитися 3 думкою К.Соколова в тому плані, що міжнародні організації, структури в умовах сучасної глобалізації покликані в першу чергу дбати про відстоювання таких загальнолюдських цивілізаційних орієнтирів як сталий розвиток суспільств, соціальна справедливість, права i свободи людини, демократизація життя $[14$, с.115]. При цьому характерно, що у сучасному світі найпомітніших успіхів у розвитку набули ті держави, що зуміли діалектично поєднати розвиток власних соціальних систем з кращими світовими зразками у цій царині, але не просто запозичили і штучно перенесли такі зразки на свій національний грунт. Як справедливо зазначає В.Співак «Глобалізація не скасовує національну державу, а трансформує їі роль і функції» [15, с.351].

Щодо міжнародного співробітництва, то в умовах глобалізації воно може бути плідним лише за умови спільної політичної волі, яка максимально враховує як національні інтереси окремих країн, так і загальноцивілізаційні інтереси. Вибудова міжнародного співробітництва за такої моделі на початку XXI століття виявилася надзвичайно складним завданням. Тут даються взнаки багато факторів, серед яких виділяємо: а) різний рівень соціально-економічного розвитку; б) проблеми культури, ментальності, історичних традицій (центральна проблема мультикультуралізм); в) геополітичний вектор i т. ін. Окрім міждержавних відносин, гостро постала проблема загальносвітових, міжнародного рівня органів, що координували би міжнародне співробітництво, оскільки створена у 1945 році ООН нині, на думку багатьох політиків, державних діячів функцію такого органу фактично виконує незадовільно. В економічному плані співробітництва країн не меншій критиці піддається Група Всесвітнього Банку, в духовно-культурноморальному плані - ЮНЕСКО і т. ін.

Критика сучасних міжнародних організацій, що значною мірою покликані 
зменшувати негативні наслідки глобалізацій, більш раціонально впорядковувати світові міжнародні відносини не $є$ риторичною. Крім того, останнім часом все більше посилюється тенденція коли окремі сильні держави навіть чинять певний опір таким інституціям, відмовляються виконувати їх рішення й рекомендації, дбаючи виключно про зміцнення власного суверенітету.

В умовах глобалізаційних процесів у XX - на початку XXI століття надто гостро постали проблеми геополітичного характеру. Основою такої проблематики стали: надто різноманітне просторове находження держав; ситуація із природними ресурсами; кількість населення і демографічна проблема; кліматичні відмінності. Як вважав шведський державотворець, географ Р.Челлен (йому, нібито, належить першому вживання терміну «геополітика») - геополітика - це наука про державу як специфічний географічний організм, що втілений у певному просторі.

Так чи інакше, але глобалізаційні процеси найвідчутніше позначилися як на просторово-географічному розташуванні держав, так і на їх взаєминах. 3 кінця XX століття на вказані процеси найпомітніший вплив мали: розпад СРСР та так званого соціалістичного табору; розпад Югославії; помітна втрата домінуючих позицій у світі США; об’єднання Німеччини, суттєві трансформації багатьох країн і суспільств фактично в усіх регіонах світу. Тобто, світовий порядок набув нових, принципових ознак, які в умовах глобалізації потребують більш глибокого наукового осмислення і пояснення.

В даній статті не дається відповідь, мабуть, на найгостріше питання: глобалізація - добро чи зло, позитив чи негатив. А тому є потреба зробити таке зауваження. Авторська позиція у цьому неоднозначному питанні збігається 3 думкою відомого сучасного економіста Джозефа Стигліца, який пише: «Користь від глобалізації досить часто була набагато меншою, ніж стверджували іï захисники, a iï ціна набагато вищою, оскільки розвалювалось оточуюче середовище, в політичні процеси проникала корупція, i, окрім того, швидкі зміни не давали країнам часу для культурної адаптації. Кризи, за якими наступало масове безробіття, викликали за собою більш довгочасні проблеми розпаду соціальних структур - від актів насилля в Латинській Америці до етнічних конфліктів в інших частинах світу, наприклад, в Індонезії» [8, с.27]. Тобто, незаперечним $є$ факт, що людство сьогодні має набагато більше робити для того, аби глобалізація сприяла прогресивним засадам розвитку суспільств, ніж просто користуватися позитивними їі наслідками.

\section{Висновки.}

1. На початковій стадії розгортання світових глобалізаційних процесів існували гіпотетичні уявлення про те, що завдяки їм підвищиться рівень життя багатьох народів та різко активізуються механізми стихійної саморегуляції життя 
людей на відміну від свідомого планування й управління. Більше того, піддавалася сумніву роль державного регулювання усіма суспільними процесами. Цього не відбулося, навпаки, - глобалізація породила ще більшу поляризацію людства на багатих і бідних, протиріччя між країнами поглибилися у сферах не лише економіки але й політики, культури тощо. Отже, є всі підстави погодитися 3 доречною думкою українського політолога В.Співака, який зазначає, що «глобалізацію не можна розглядати як звичайну лінійну схему хоча б тому, що вона в своїй екзистенції вміщує одночасно як розвиток, так і руйнацію, стосується найважливішого - соціальної царини людини» [14, с.14]. Тобто, глобалізація стимулює новий соціальний i інший розвиток людини i, одночасно, породжує численні проблеми такого розвитку.

2. Глобалізація нині постає як багатовимірний процес людського розвитку, що характеризується не лише складністю i неодновимірністю але й інтеграційними і дезінтеграційними процесами людського буття в усіх його сферах. Як вірно зазначає А.Чумаков: «Глобалізація - це тривалий у часі й природний процес становлення для всієї планети біосоціальних структур, зв'язків і відносин; глобальні проблеми - результат цього процесу; а глобалістика - сфера теорії і практики, в центрі уваги якої перебуває глобалізація і глобальні проблеми [16, с.87]. Маємо брати до уваги й те, що у глобалізації, як неоднозначному i досить протирічливому процесі тісно переплітаються об'єктивне і суб'єктивне, свідоме і несвідоме, хаотичне і цілеспрямоване.

3. Дослідження глобалізації не дає і ближчим часом не дасть більш-менш однозначних оцінок цього феномену. $Є$ можливість і підстави лише прогнозувати, що у майбутньому в процесі глобалізації ще більш помітними будуть економічні [5, с.313], інформаційно-комунікативні [9], соціокультурні [13] та інші аспекти людського існування і розвитку [2]. Отже, цю особливість іiі розвитку слід особливо враховувати як на національному, так і світовому, міжнародному рівнях.

4. Оскільки творцем глобалізації $є$ люди, народи, то i ставлення до глобалізації є досить різним. При цьому глобалізацію слід розглядати як загальноцивілізаційне й національне явище, а також явище економічне, політичне, маркетингове, екологічне, культурне, релігійне і т. ін. Йдеться про потребу більш глибокого, комплексного дослідження процесів глобалізації. «Уся практична мудрість людська, - писав великий гуманіст М.Драгоманов ще у XIX столітті, може бути в тому, щоб убачити напрямок руху світового, його міру, закон i послужитись тим рухом. Інакше той рух піде проти нас, розчавить нас» [4, с.13].

5. В умовах сучасної глобалізації багато суспільних процесів носять об'єктивний і незворотній характер. I все ж, людство може мріяти і сподіватися на щасливе майбутнє лише за умови, коли зуміє знайти вірні відповіді і віднайде 
дієві підходи до вирішення тих гострих проблем, які нагромадила, знову ж таки, глобалізація. «Ми маємо усвідомити, - зазначає Д.Капур, - що світ - це все велика дорога для «економічної діяльності» глобалізаторів» але в повному сенсі сім'я націй, де усі члени мають право молитися, працювати і вибирати спосіб життя на свій смак» [7, с.32]. Без широкого суспільного діалогу напрацювання засобів, що зможуть забезпечити кардинально нове співробітництво країн i народів, унеможливить загрозу ще більш гострого зіткнення цивілізацій, розв’язати цю проблему не вдасться.

6. Досить важко прогнозувати, у який спосіб виглядатиме з часом, в умовах глобалізації світова система держав, які цінності і норми облаштування життя людей домінуватимуть у світі, якими будуть взаємини між країнами і народами, але те, що вони будуть суттєво трансформованими - сумнівів не викликає.

\section{Лimepamypa:}

1. Бебик В.М. Глобальне громадянське суспільство: проблеми теорії і методології дослідження // Трансформація політичних систем на постсоціалістичному просторі: Матеріали міжнародної науково-практичної конференції, 8-9 лютого 2006 р. / укл. Г.О.Нестеренко / за ред. В.П.Беха. К.: НПУ імені М.П.Драгоманова. 2006. 364 с. с.78.

2. Богатырева Т.Г. «Синергетика глобальных социокультурных процессов и культурная политика [Електронный ресурс] / Богатырева Т.Г. Режим доступа: spkurdyamon.narod.ru/D46Ba gatireva.htm.

3. Герст П. Сумніви в глобалізації. Міжнародна економіка і можливості керування / П.Герст, Г.Томпсон. К.: К.I.С. 2002. 306 с.

4. Глобалізація і безпека розвитку: монографія / О.Г.Білорус, Д.Г.Лук'яненко та ін.; Кер. авт. кол. і наук. ред. О.Г.Білорус. К.: КНЕУ. 2001. 733 с.

5. Глобалізация: учебник /под общ. ред. В.А.Михайлова, В.С.Буянова. М.: Изд-во РАГС. 2008.544 c.

6. Горбатенко В.П. Політична трансформація у сучасному світі / В.П.Горбатенко, С.С.Бульбенюк: навч. посібник. К.: ДП «Вид. дім «Персонал». 2010. 160 с.

7. Джагдиш Капур. Опасность монокультурализма: время размышлений // Мировой общественный форум «диалог цивилизаций» // Вестник № 1. 2005. М.: Андреевский флаг. 2005. 284 c. C. $27-32$.

8. Дж.Стиглиц. Глобализация: тревожные тенденции. М.: Прогресс. 2003. 491 с.

9. Димаров Яшар Рафаэль огли. Современная глобализация как подчинение мировой экономики // Діалог цивілізацій чи Четверта світова війна: Матеріали Пятої Всесвітньої конференції. Київ, 25 травня 2006 р. К.: МАУП. 2007. 284 с. с.202-219.

10. Зернецька О.В. Глобальна трансформація систем масової комунікації. Автореф. дис...докт. політ. наук: 23.00.04 - політичні проблеми міжнародних систем і глобального розвитку. К. 2000.34 с.

11. Клочко В.П. Глобалізація: економічні та соціокультурні аспекти: монографія. К.: ДАКККіМ. 2005. 189 с.

12. Предборська I.M. Мінливість, соціум, людина: монографія. Суми: Видавництво «Слобожанщина». 1995. 451 с. 
13. Румянцев А.П., Румянцева Н.С. Міжнародна економіка: короткий конспект лекцій. К.: МАУП. 1999. 104 с.

14. Соколов К.Б. Глобализация культури и культура глобализациії / Соколов К.Б. // Культура на рубеже XX-XXI веков: глобализационные процессы. СПб: Нестор-История. 2009. №2(28). C.36-39.

15. Співак В.М. Політико-правовий та соціокультурний вимір глобалізації: монографія. К.: Логос. 2011. 416 c.

16. Халамендик В. Мораль і політика: теорія відносин / Халамендик В. // Віче. 2010. № 3(254). С.10-13.

17. Чумаков А.Н. Глобализация. Контуры целостного мира: монография 2-е изд. перераб. и доп. М.: Проспект. 2009. 432 с.

\section{References:}

1. Bebik V.M. Global'ne gromadjans'ke suspil'stvo: problemi teoriï i metodologiï doslidzhennja // Transformacija politichnih sistem na postsocialistichnomu prostori: Materiali mizhnarodnoï naukovo-praktichnoï konferenciï, 8-9 ljutogo 2006 r. / ukl. G.O.Nesterenko / za red. V.P.Beha. K.: NPU imeni M.P.Dragomanova. 2006. 364 s. s.78.

2. Bogatyreva T.G. «Sinergetika global'nyh sociokul'turnyh processov i kul'turnaja politika [Elektronnyj resurs] / Bogatyreva T.G. Rezhim dostupa: spkurdyamon.narod.ru/D46Ba gatireva.htm.

3. Gerst P. Sumnivi v globalizaciï. Mizhnarodna ekonomika i mozhlivosti keruvannja / P.Gerst, G.Tompson. K.: K.I.S. 2002. 306 s.

4. Globalizacija i bezpeka rozvitku: monografija / O.G.Bilorus, D.G.Luk'janenko ta in.; Ker. avt. kol. i nauk. red. O.G.Bilorus. K.: KNEU. 2001. 733 s.

5. Globalizacija: uchebnik /pod obshh. red. V.A.Mihajlova, V.S.Bujanova. M.: Izd-vo RAGS. 2008. $544 \mathrm{~s}$.

6. Gorbatenko V.P. Politichna transformacija u suchasnomu sviti / V.P.Gorbatenko, S.S.Bul'benjuk: navch. posibnik. K.: DP «Vid. dim «Personal». 2010. 160 s.

7. Dzhagdish Kapur. Opasnost' monokul'turalizma: vremja razmyshlenij // Mirovoj obshhestvennyj forum «dialog civilizacij»// Vestnik № 1. 2005. M.: Andreevskij flag. 2005. 284 s. S. 27-32.

8. Dzh.Stiglic. Globalizacija: trevozhnye tendencii. M.: Progress. 2003. $491 \mathrm{s.}$

9. Dimarov Jashar Rafajel' ogli. Sovremennaja globalizacija kak podchinenie mirovoj jekonomiki // Dialog civilizacij chi Chetverta svitova vijna: Materiali Pjatoï Vsesvitn'oï konferenciï. Kiïv, 25 travnja 2006 r. K.: MAUP. 2007. 284 s. s.202-219.

10. Zernec'ka O.V. Global'na transformacija sistem masovoï komunikaciï. Avtoref. dis...dokt. polit. nauk: 23.00.04 - politichni problemi mizhnarodnih sistem i global'nogo rozvitku. K. $2000.34 \mathrm{~s}$.

11. Klochko V.P. Globalizacija: ekonomichni ta sociokul'turni aspekti: monografija. K.: DAKKKiM. 2005. 189 s.

12. Predbors'ka I.M. Minlivist', socium, ljudina: monografija. Sumi: Vidavnictvo «Slobozhanshhina». 1995. $451 \mathrm{~s}$.

13. Rumjancev A.P., Rumjanceva N.S. Mizhnarodna ekonomika: korotkij konspekt lekcij. K.: MAUP. 1999. 104 s.

14. Sokolov K.B. Globalizacija kul'turi i kul'tura globalizaciiï / Sokolov K.B. // Kul'tura na rubezhe HH-HHI vekov: globalizacionnye processy. SPb: Nestor-Istorija. 2009. №2(28). S.36-39. 
15. Spivak V.M. Politiko-pravovij ta sociokul'turnij vimir globalizaciï: monografija. K.: Logos. 2011. $416 \mathrm{~s}$.

16. Halamendik V. Moral' i politika: teorija vidnosin / Halamendik V. // Viche. 2010. № 3(254). S.10-13.

17. Chumakov A.N. Globalizacija. Kontury celostnogo mira: monografija 2-e izd. pererab. i dop. M.: Prospekt. 2009. 432 s. 